\title{
A Mini Review on Alphonsea sp. (Annonaceae): Traditional uses, Biological Activities and Phytochemistry
}

\author{
Yuhanis Mhd Bakri*, Munirah Abdul Talip, Saripah Salbiah Syed Abdul Azziz \\ Department of Chemistry, Faculty of Science and Mathematics, UniversitiPendidikan Sultan Idris, 35900, Tanjong Malim, Perak, Malaysia.
}

\author{
ARTICLE INFO \\ Article history: \\ Received on: 15/06/2017 \\ Accepted on: 30/08/2017 \\ Available online: 30/10/2017 \\ Key words: Alphonsea, \\ Annonaceae, Biological \\ Activities, Phytochemistry, \\ Bioactive compounds.
}

\begin{abstract}
The genus Alphonsea belongs to the family Annonaceae, which comprises of about 30 species, consisting of small trees and shrubs are distributed in China and Indo-Malayan. In this mini review, we aim to provide an overview of the traditional uses, biological activities and phytochemistry of plants Alphonsea sp. Literature, abstract and full text articles from journals, books, reports and electronic searches as well as from other relevant websites are surveyed, analysed and included in this review. The crude extracts exhibit anti-cancer, anti-oxidant, anti-fungal, anti-inflammatory and anti-trypanasomal activities. The survey reveled that Alphonsea sp. contain alkaloids, steroids, lignan, sesquiterpenes and monoterpenes.
\end{abstract}

\section{INTRODUCTION}

Alphonsea is a small genus of the family Annonaceae, distributed in China and Indo-Malayan. In China, the species mainly found in Hainan and South Yunnan, while in Asia, the Alphonsea species can be found in India, Sri Lanka, Myanmar, Thailand, Laos, Vietnam, Cambodia, Malaysia, Indonesia and Papua New Guinea (Srivastava \& Mehrotra, 2013). Genus Alphonsea were narrowly distributed and poorly known species scattered throughout tropical Asia. In Malaysia, the species that can be found are A. borneensis, A. curtisii, A. cylindrica,

\footnotetext{
* Corresponding Author

Yuhanis Mhd Bakri, Department of Chemistry, Faculty of Science and Mathematics, UniversitiPendidikan Sultan Idris, 35900, Tanjong Malim, Perak. Phone: +601548797746; Email: yuhanis.mb @ fsmt.upsi.edu.my
}

A. elliptica, A. johorensis, A. maingayi and A. rugosa (Turner, 2009; Latiff, 2013; Turner and Utteridge, 2015; Turner, 2016). Additionally, A. hainanensis, A. monogyma and A. tsangyuanensis have been listed as endangered species (IUCN Red List, 2010).

According to Turner (2009), the fruits of A. javanica were similar with $A$. borneensis, but it has more cylindrical monocarps to $2.5 \mathrm{~cm}$ in diameter whereas those of $A$. borneensis are ellipsoidal, or more rarely globose, and reach $4 \mathrm{~cm}$ in diameter. The obvious difference between A. javanica and A. borneensis is in the leaves. A. javanica has chartaceous leaves with a shiny upper surface, whereas $A$. borneensis has chartaceous leaves with a smooth but not markedly shiny upper surface. A. rugosa is similar to A. elliptica. The differences are A. rugosa have more carpels per flower than A. elliptica, with strongly wrinkled and globrous of monocarp surface, while $A$. elliptica have smooth and hairy surface (Turner and Utteridge, 2015). The leaves of $A$. kingii were similar to those of A. elliptica and A. johorensis (Turner, 2016). 


\section{Traditional use}

There are several uses of the plant parts of this plant. The ripe fruits of A. ventricosa, A. mollis, A. hainanensis and A. lutea are edible (Kar et al., 2013; Shu et al., 2011). The wood of A. mollis, A. hainanensis and A. monogyma were used for the construction of carts and agricultural implements. In addition, the wood of the Indian A. ventricosa was used in boat building in the Andamas (Burkill, 1966). Besides that, the flowers of A. monogyma are also fragrant and used for perfumery (Shu et al., 2011). According to Batugal et al. (2004), the boiled fruits of $A$. arborea have been traditionally used for the treatment of diarrhoea, reducing fever and emmenagogue or stimulating menstrual flow. However, the leaves of A. ventricosa and A. javanica have been reported to be poisonous (Burkill, 1966).

\section{Biological activities}

A thorough survey on biological activities of Alphonsea species revealed that not many studies and results were found. According to Horgen et al. (2001), the root extract of an unnamed Alphonsea species, was shown cytotoxic to brine shrimp at a concentration of $100 \mu \mathrm{g} / \mathrm{ml}$ and known to be anti-cancer against various cancer cell lines such as human epidermoid carcinoma and murine lymphoid neoplasm cancer cell with $\mathrm{IC}_{50} \leq 20 \mu \mathrm{g} / \mathrm{ml}$. Besides that, the ethanolic extract of A. sclerocarpa showed significant free radical scavenging property by inhibiting the DPPH free radical. The ability of A. sclerocarpa bark extracts to inhibit the hydroxyl-free radical production has also been evaluated and was found to be very promising (Narendra, 2009). In addition, anti-fungal activity of $A$. sclerocarpa against Aspergillus flavus, fungal organism that usually associated with dandruff, showed moderate anti-fungal activity compared with local herbs shampoo (Indrani et al., 2015). According to Johnson et al. (2013), methanol extract of Indonesian A. javanica also possessed anti-inflammatory activity while the methanol extract of A. maingayii leaves and stem had been studied for antitrypanosomal with $\mathrm{IC}_{50}>12.5$ (Norhayati et al., 2013).

\section{Phytochemistry}

There were only a few studies on chemical compounds present in genus Alphonsea have been reported (Figure 1). Previous phytochemical investigations carried out by Xie et al., (1989, 1994) on the stem bark and bark of A. mollis, revealed isolation of 2,6-dimethoxy-5-hydroxy onychine (1), liriodenine (2), oxostephanine (3), mollisine (4), (2R,3R)-2,3-dihydro-2-(4hydroxy-3-methoxyphenyl)-3-methyl-5-(E)-propenylbenzofuran

(5) and conocarpan (6). In 1999, Yang and Xie reported azafluorenone alkaloid, 6, 7-dimethoxy-5-hydroxy onychine (7) and other alkaloid, liriodenine (2), cyathocaline (8), isooncodine (9) and darienine (10) from stem and branch of A. monogyma. Thang et al. (2013) reported glaucine (11) and nor-glaucine (12) were found from A. ventricosa. According to Tadić et al., (1987), the isolation of chemical compounds from barks of A. sclerocarpa revealed the presence of liriodenine (2), anonaine (13), norushinsunine (14), ushinsunine (15), stepharine (16), stepholidine (17), candicine (18), phenethyltrimethylammonium (19) and magnoflorine (20). On the other hand, the leaves of $A$. sclerocarpa have been found to contain crotsparine (21), sparsiflorine (22), laurotetanine (23), isoboldine (24), liriodenine (2) and petaline methane (25). In addition, Jalil et al. (2015) also had reported three steroids isolated from Malaysian A. curtisii; stigmasta-4, 6, 22-trien-3-one (26), stigmast-22-ene-3,6-dione (27) and stigmast-22-ene-3-one (28).

The chemical constituents of the essential oil content identified in two species of Alphonsea, A. philastreana and A. gaudichaudiana were reported in which sesquiterpenes; bicyclogermacrene (29) $(9.3 \%, 6.3 \%)$, guaiol (30) $(9.0 \%, 5.2 \%)$, bicycloelemene (31) $(8.9 \%, 6.3 \%), \gamma$-eudesmol (32) $(8.3 \%, 5.5 \%)$, $\beta$-caryophyllene $(33)(5.1 \%, 5.9 \%)$ and monoterpene (E)- $\beta$ ocimene (34) $(6.9 \%, 8.5 \%)$ were found in both species, respectively (Thang et al., 2013). In A. philastreana, additional sesquiterpene, $\alpha$-humulene (35) (5.8\%) and monoterpene $\beta$-pinene (36) $(4.6 \%)$ were reported, whilst sesquiterpeneviridiflorol (37) (6.0\%) was found A. gaudichaudiana.

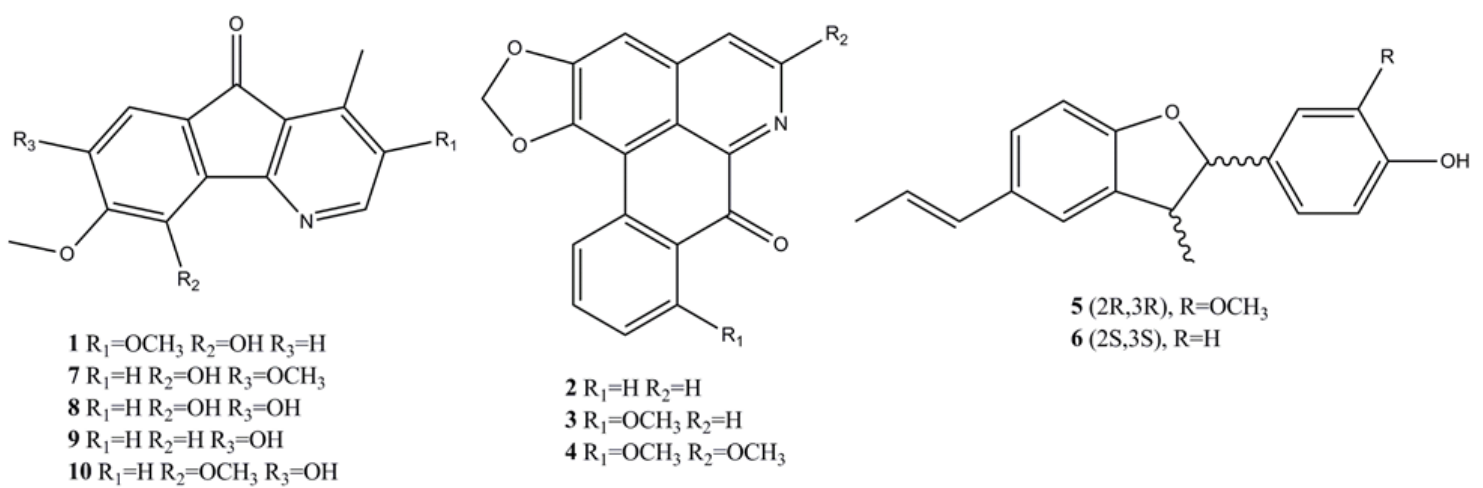

Figure 1 
<smiles>[R]N1CCc2cc(OC)c(OC)c3c2C1Cc1cc(OC)c(OC)cc1-3</smiles>

$11 \mathrm{R}=\mathrm{CH}_{3}$ $12 \mathrm{R}=\mathrm{H}$<smiles></smiles>

$13 \mathrm{R}_{1}=\mathrm{H} \mathrm{R}_{2}=\mathrm{H}$ $14 \mathrm{R}_{1}=\mathrm{OH} \mathrm{R}_{2}=\mathrm{H}$ $15 \mathrm{R}_{1}=\mathrm{OH} \mathrm{R}_{2}=\mathrm{CH}_{3}$<smiles>[R]Oc1cc2c3c(c1OC)C1(C=CC(=O)C=C1)CCNC3CC2</smiles>

$16 \mathrm{R}=\mathrm{CH}_{3}$ $21 \mathrm{R}=\mathrm{H}$<smiles>COc1cc2c(cc1O)[C@H]1Cc3ccc(O)c(OC)c3CN1CC2</smiles>

17

$18 \mathrm{R}=\mathrm{OH}$ $19 \mathrm{R}=\mathrm{H}$<smiles>COc1ccc2c(c1O)-c1c(O)c(OC)cc3c1[C@@](C)(C2)N(C)CC3</smiles>

20<smiles>[R]Oc1cc2c(cc1[R])C[C@@]1([2H])c3c(cc(OC)c(O[R])c3-2)CCN1CC</smiles>

$22 \mathrm{R}_{1}=\mathrm{HR}_{2}=\mathrm{H} \mathrm{R}_{3}=\mathrm{H} \mathrm{R}_{4}=\mathrm{H}$ $23 \mathrm{R}_{1}=\mathrm{H} \mathrm{R}_{2}=\mathrm{OH} \mathrm{R}_{3}=\mathrm{CH}_{3} \mathrm{R}_{4}=\mathrm{CH}_{3}$ $24 \mathrm{R}_{1}=\mathrm{CH}_{3} \mathrm{R}_{2}=\mathrm{OH} \mathrm{R} \mathrm{R}_{3}=\mathrm{CH}_{3} \mathrm{R}_{4}=\mathrm{H}$<smiles>CCC(/C=C/C(C)C1CCC2C3CCC4CC(=O)CC[C@]4(C)C3CC[C@]12C)C(C)C(C)/C=C/C(C)C1CCC2C3CC(=O)C4CC(=O)CC[C@]4(C)C3CC[C@]12C</smiles>

28

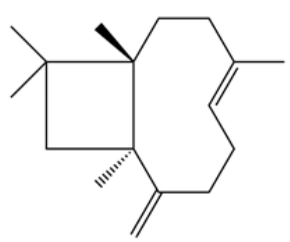

33<smiles>CC1=CCCC(C)=CCC(C)(C)C=CC1</smiles>

34<smiles>C/C=C\CC/C(C)=C/C1C(CC/C=C\C)C1(C)C</smiles>

29<smiles>C=C1CCC2CC1C2(C)C</smiles>

36

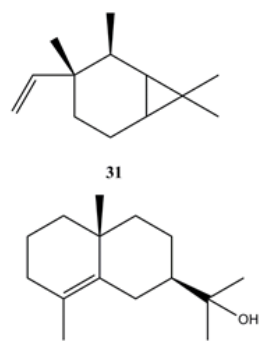

32

Fig. 1: Chemical compounds of Alphonsea sp.

\section{CONCLUSION}

Alphonsea sp. which were found from north-eastern India and southern China southwards to Ceylon and Malaysia were surveyed. Many pharmacological studies have been performed on crude extracts and these extracts exhibit anti-cancer, anti-oxidant, anti-fungal, anti-inflammatory and anti-trypanasomal activities. Phytochemical studies show that they contain alkaloids, steroids, lignan, sesquiterpenes and monoterpenes. The discovery of novel compounds from Alphonsea sp. is much rarer, as indicated by the fact that no publication have described isolation of novel compounds. In addition, many species of Alphonsea species remain to be investigated, therefore, further study should be conducted on these species especially on understanding their phytochemistry and biological activities.

\section{ACKNOWLEDGEMENT}

Financial support and sponsorship: The research was funded by the Universiti Pendidikan Sultan Idris Research Special Grant (2017-0009-101-01). 
Conflict of Interests: There are no conflicts of interest.

\section{REFERENCES}

Burkill IH. 1966. A Dictionary of Economic Products of the Malay Peninsular. Vol.1.Reprint. Kuala Lumpur: Ministry of Agriculture \& Cooperatives.

Horgen FD, Edrada RA, Reyes G, Agcoili F, Madulid DA, Wongpanich V, Angerhofer CK, Pezzuto JM, Soejarto DD, Farnworth NR. Biological screening of rain forest plot trees from Palawan Island (Philipines). Phytomedicine, 2001; 8(1):71-81.

Hussain I, Khattak MUR, Ullah R, Muhammad Z, Khan N, Khan FA, Ullah Z, Haider S. Phytochemicals screening and antimicrobial activities of selected medicinal plants of Khyberpakhtunkhwa Pakistan. Afr J Pharm Pharmacol, 2011; 5(6): 746-750.

Indrani V, Madhuri T, Lakshmi KB, Suvarnalatha DP. Invitro comparative antifungal studies of Alphonsea sclerocarpa with local herbal shampoo against clinically isolated Aspergillus flavus. Int J Sci Res Manag Stud. 2015; 3(2): 2103-2105.

IUCN Red List of Threatened Species. Retrieved from http://www.iucnredlist.org/.JabatanPerhutananSemenanjung Malaysia 2010.

Jalil J, Teh CH, Hussain K, Jamal JA, MohamadHF, Muhammad K. Steroids from Alphonsea curtisii King. propelling science and technology through natural products. International Conference on Natural Products 2015. March 2015. Skudai, Johor.

Johnson TA, Sohn J, Ward AE, Cohen TL, Lorig-Roach ND, Chen H, Pilli RA, Widjaja EA, Hanafi M, Kardono LBS, Lotulung PD, Boundy-Mills K, Bjeldanes LF. (2013). (+)-Altholactone exhibits broad spectrum immune modulating activity by inhibiting the activation of proinflammatory cytokines in RAW 264.7 cell lines. Bioorg Med Chem, $2013 ; 21: 4358-4364$.

Kar A, Bora D, Borthakur SK, Goswami NK,Saharia D. Wild edible plant resources used by the mizos of Mizoram, India. Kathmandu University J Science, Eng and Tech, 2013; 9(1): 106-126.

Latiff A. On the Annonaceae of Taman Negara, Peninsular Malaysia. Malayan Nat J, 2013; 65(4): 247-273.

Manosalva L, Mutis A, Urzúa A, Fajardo V, Quiroz A. Antibacterial activity of alkaloid fractions from Berberis microphylla $\mathrm{G}$. Frost and study of synergism with Ampicillin and Cephalothin. Molecules, 2016; 21(76): 1-10.
Narendra PD. Antioxidant Activity of Alphonseas clerocarpa Bark. Res J Pharmacol Pharmacodynamics. 2009; 1(2):66-69.

Norhayati I, Getha K, Haffiz JM, Ilham AM, Sahira HL, SitiSyarifah MM, Syamil M. In vitro antitrypanosomal activity of Malaysian Plants. J Trop ForSci, 2013: 25 (1): 52-59.

Shu TC, Bingtao L, Gilbert MG.Alphonsea J. D. Hooker \&Thomson. F1 China, 2011; 19: 699-700.

Srivastava G, Mehrotra RC. First fossil record of AlphonseaHk. $\mathrm{f} \& \mathrm{~T}$. (Annonaceae) from the late oligocene sediments of Assam, India and comments on its phytogeography. PLoS ONE, 2013; 8(1): 1-6.

Tadić D, Wanningama GP, Cassels BK, Cavé. Alkaloids of Alphonseasclerocarpa. J Nat Prod, 1987; 50:518-519

Thang TD, Huong LT, Dai DN, Oguwande IA. (2013). Essential oil compositions of Alphonsea philastreana (Pierre) Pierre ex Finet and Gagnepand Alphonsea gaudichaudiana (Baill) Finet and Gagnep from Vietnam. Nat Prod Res, 2013; 27(21): 2022-2026.

Turner IM. A New Species of Alphonsea (Annonaceae) from Borneo. Gard. Bull. (Singapore), 2009; 61: 185-188.

Turner IM, Utteridge TMA. A new species of Alphonsea (Annonaceae) from Peninsular Malaysia. Blumea, 2015; 59: 206-208.

Turner, IM. Notes on the Annonaceae of the Malay Peninsula. Gard. Bull. (Singapore), 2016; 68:65-69.

Xie N, Zhong S, Zhao S, Peter GW. Study on the major alkaloids from Alphonsea mollis. J China Pharm Univ,1989; 20(6):321324

Xie N, Renan X, Shouming Z,Shouxun Z. Chemical investigation on Alphonseamollis Dum. J China Pharm Univ, 1994; 205.

Xie N, Yang NY. A new azafluorenone alkaloid from Alphonsea monogyma. Chin ChemLett, 1999:10 (8): 671-672.

\section{How to cite this article:}

Bakri YM, Talip MA, Abdul Azziz SS. A Mini Review on Alphonsea sp. (Annonaceae): Traditional uses, Biological Activities and Phytochemistry. J App Pharm Sci, 2017; 7 (10): 200-203. 